\title{
PERSPECTIVE ASUPRA EVOLUȚIEI \\ GARANȚIEI PENTRU EVICȚIUNE ÎN DREPTUL
}

\author{
ROMAN
}

DOI: $10.24193 /$ SUBBiur.65(2020).4.9

Data publicării online:

16.03 .2021

\section{Juanita GOICOVICI*}

Rezumat: Garanția de evicțiune este adesea văzută ca un corolar al obligației vânzătorului de a transfera posesiunea durabilă, pașnică și utilă asupra bunurilor vândute; cu toate acestea, evoluția sa, în dreptului roman, precum și rădăcinile sale conceptuale merită o abordare detaliată. Studiul examinează auctoritas ulterior unei mancipatio, care a ajuns să desemneze, în locul actului material și concret al asistenței judiciare într-un proces, obligația de a asigura această asistență și, ulterior, actul translativ de proprietatea în virtutea căruia se naște acest tip de obligație, ținând cont de faptul că, la originile primare ale conceptului de auctoritas, se poate regăsi asistența oferită de vânzător cumpărătorului său Analiza cuprinde și extinderea progresivă a stipulatio duplae, în vânzările de rei mancipi sine mancipio, precum și în cazul transferului rei nec mancipi. Se poate observa modul în care caracteristicile procedurii auctoritas sunt conturate ca reprezentând caracteristicile unei acțiuni penale sau, mai precis, ale unei acțiuni cu o natură mixtă, recunoscută victimei unui delict privat.

Cuvinte cheie: garanție de evicțiune, mancipațiune, stipulație, cumpărător, drept roman.

* Lect. univ. dr. la Facultatea de Drept, Universitatea Babeș-Bolyai Cluj-Napoca, juanita.goicovici@law.ubbcluj.ro. 


\title{
PERSPECTIVES ON THE EVOLUTION OF THE VENDOR'S WARRANTY AGAINST EVICTION IN ROMAN LAW
}

\begin{abstract}
The vendor's warranty against eviction is often seen as a corollary of the vendor's obligation to transfer the durable, satisfactory and tangible possession on the sold goods; however, its evolution under the Roman Law, as well as its conceptual roots deserve a detailed approach. The study examines the auctoritas subsequent to the completion of a mancipatio, which had been designating, instead of the material and concrete act of judicial assistance in a court of law, the obligation to provide for this assistance and later the transferring of property act generating this type of obligation, while keeping in mind that, at the origins of the conception on the auctoritas one can find the vendor's duty to assist the buyer in court when confronted with the third party's attempt of eviction. The analysis also encompasses the progressive extension of the stipulatio duplae, in the perimeter of the transfer of rei mancipi sine mancipio, as well as in the case of the rei nec mancipi transferring. One may observe the manner in which the features of the auctoritas procedure are contoured as depicting the characteristics of a tort action or, more specifically, of an action of a mixt judicial nature valorising the plaintiff's rights consequential to the eviction.
\end{abstract}

Keywords: warranty against eviction, mancipatio, purchaser, Roman Law.

\section{PERSPECTIVES SUR L'ÉVOLUTION DE LA GARANTIE D'ÉVICTION EN DROIT ROMAIN}

Résumé. La garantie d' éviction est souvent vue comme étant le corollaire de l' obligation du vendeur de transferrer la possession durable, paisible et utile sur la chose vendue, mais son evolution en droit romain et ses racines conceptuelles méritent une approche détaillée. On examine l'auctoritas subséquent à une mancipatio, qui est arrivé à désigner au lieu de cet acte matériel et concret d' assistance dans un procés, l' obligation de fournir l' assistance, puis l' acte translatif de propriété à raison duquel cette obligation se produisait, compte tenue que dans l' acception primitive, l' auctoritas est l' assistance fournie par le mancipant à son acquéreur. On analyse aussi l' extension progressive de la stipulatio duplae, dans les ventes des rei mancipi sine mancipio, aussi que dans les ventes des rei nec mancipi. 
On voit que les lignes de la procedure d'auctoritas se dessinent comme caracteristiques d'une action pénale ou, plus exactement, une action mixte appartenant à la victime d' un délit privé.

Mots-clés: garantie d' éviction, mancipation, stipulation, acquéreur, droit romain.

Cuprins

I. Observații introductive.

330

A. Problematica și cadrul contextual al evingerii cumpărătorului în cazul bunurilor mancipi. 332

B. Specificitatea efectelor vânzării consensuale romane .333

II. Regimul lui actio auctoritatis, anterior configurării răspunderii obiective pentru evicțiune 334

A. Actio auctoritatis, ca acțiune în reprimarea unui delict 334

1.Actio auctoritatis: efect automat al mancipatiunii sau pact accesoriu? 334

2.Postulo anne auctor fias.

B. Nexum mancipiumque: un clivaj aparent? 338

III. Stipulațiile conexe vânzării și stipulatio duplae: remedii contra evicțiunii?341

A. Mecanismele juridice ale satisdatio secundum mancipium sau repromissio secundum mancipium. garanții pentru vacua possessio?

B. Cum funcționa stipulatio rem habere licere? 344

IV. Există un automatism al garantării pentru evicțiune în dreptul roman clasic? 345

A. Garanția pentru evicțiune în vânzarea consensuală 345

B. Denuntiandi necessitas: consecințele omiterii chemării în garanție a vânzătorului 349

V. Configurația garanției pentru evicțiune în dreptul român contemporan.. 350

VI. Concluzii 359

VII. Bibliografie 363 


\section{Observații introductive.}

Panoplia garanțiilor atașate dreptului de proprietate nu ar fi completă în niciun sistem de drept evoluat, în absența garanției pentru evicțiune, datorate de vânzător cumpărătorului.

Corolarul obligației vânzătorului de transferare a posesiunii liniștite și durabile, garanția pentru evicțiune a cunoscut în dreptul roman un traseu sinuos, fără a fi unul abisal. Trecând prin rigorile lui actio auctoritatis în vânzările încheiate prin mancipatio, luând apoi înfățișarea stipulațiilor voluntare de garanție justificate la sfârșitul sec. I p. Chr. prin exigențele buneicredințe contractuale, pentru a deveni, în prima jumătate a sec. II p. Chr., un efect natural și direct al contractului de vânzare, în mulajul unei răspunderi obiective $^{1}$, funcționând independent de vinovăţia vânzătorului, garanția pentru evicțiune a cunoscut o evoluție spectaculoasă. Ne-am propus să abordăm, în paragrafele care urmează, condițiile de introducere a lui actio auctoritatis, insistând asupra implicațiilor lui stipulatio duplum, prin care vânzătorul promitea cumpărătorului să-i plătească dublul prețului încasat, în cazul în care acesta va fi evins, ceea ce atrăgea, în cazul evicțiunii totale, consecința achitării către cumpărător a dublului prețului vânzării² independent de fluctuațiile valorice înregistrate de bunul vândut. Natura juridică a acțiunilor din categoria actio auctoritatis rămâne controversată, susținându-se atât caracterul convențional, voluntar al acesteia, ca rezultat al

\footnotetext{
${ }^{1}$ C. Hochart, La garantie d'éviction dans la vente, L.G.D.J, Paris, 1993, p. 186-188.

${ }^{2}$ R. Duminică, D. Iancu, „Quelques considérations sur l' éviction en droit comparé”, Revista Drept - Series Iurisprudentia, Universitatea „1 Decembrie 1918” Alba Iulia, nr. 12/2009, p. 122-123; V. Stoica, E. Garjau, „Practical notions regarding the contractual provision of the warranty against the eviction of selling contracts", AGORA International Journal of Juridical Sciences, nr. 2/2018, p. 85-91.
} 
convenirii unui pact accesoriu între vânzător și cumpărător cu privire la efectele eventualei evicțiuni, cât și caracterul de acțiune legală al acesteia, ca efect automat al mancipațiunii ${ }^{3}$, motiv pentru care vom aborda, de asemenea, in cuprinsul prezentului studiu, argumentele care pot contura un răspuns la întrebarea privind natura juridică a lui actio auctoritatis.

După cum sublinia profesorul Vladimir Hanga, originile acestei instituții urcă în timp până în vremea regelui babilonian Hammurabi, Codul lui Hammurabi (aprox. 1760 î. Chr.) menționând că un cumpărător care a contractat cu un fals proprietar se poate îndrepta contra vânzătorului ${ }^{4}$. Ne va preocupa, în cuprinsul prezentului studiu, evidențierea rolului jucat, în configurarea garanției pentru evicțiune, de cele trei tipuri de stipulații care alcătuiesc trepiedul pactelor accesorii ale vânzării în dreptul roman clasic: satisdatio secundum mancipium sau repromissio secundum mancipium, stipulatio duplae și stipulatio rem habere licere. Următoarea secțiune tratează problematica automatismului garantării pentru evicțiune a cumpărătorului în materia vânzării consensuale, până în timpul lui Iustinian, pentru a trasa contururile răspunderii obiective ${ }^{5}$, detaşate de elementulculpă, a vânzătorului ${ }^{6}$, astfel cum a fost aceasta moștenită în numeroase dintre legislațiile contemporane.

3 S. A. Vernea, „Warranty Against Eviction in Roman Law: A Conventional or Legal Obligation?”, în Social Economic Debates, vol. 3, nr. 1/2014, p. 66-71.

${ }^{4}$ A se vedea V. Hanga, Mari legiuitori ai lumii: Hammurabi, Iustinian, Napoleon, Ed. Lumina Lex, București, 1994, p. 40-41.

5 M. D. Bob, Obligația contractuală în dreptul roman cu trimiteri comparative la Codul civil, Ed. Universul Juridic, București, 2015, p. 168.

${ }^{6}$ M. Vols, A. Belloir, S.M. Hoffmann, A. Zuidema, „Common Trends in Eviction Research: A Systematic Literature Review”, University of Groningen Faculty of Law Research Paper Series, nr. 29, 2019, p. 23-78, disponibilă la adresa https://ssrn.com/abstract=3417681, consultată în 08.09.2020. 
Ultima parte a studiului este dedicată considerațiilor privind configurația garanției pentru evicţiune, în reglementarea Codului civil intrat în vigoare în 1 octombrie 2011. Este menținută cerința chemării în garanție a vânzătorului de către cumpărătorul acționat în judecată de un terț care pretinde că are drepturi asupra lucrului vândut, cu consecința că, fiind condamnat printr-o hotărâre intrată în puterea lucrului judecat, cumpărătorul care nu a introdus în proces pe vânzător pierde dreptul de garanție, dacă vânzătorul dovedește că existau motive suficiente pentru a se respinge cererea terțului. De asemenea, în textul art. 1706 C. civ. sunt introduse premisele pentru o garanție ascendentă contra evicțiunii, legiuitorul prevăzând că vânzătorul este obligat să garanteze contra evicțiunii față de orice dobânditor subsecvent al bunului, făă a distinge după cum dobândirea este cu titlu oneros ori cu titlu gratuit. Tot ca un element inedit, este postulată indivizibilitatea obligației de garanție pentru evicțiune în cuprinsul art. 1697 C. civ., astfel încât cumpărătorul poate antama garanția pentru evicțiune contra oricăruia dintre moștenitorii universali/cu titlu universal ai vânzătorului, cel ținut la plată având un drept de regres, în vreme ce bligația vânzătorului de a repara prejudiciul suferit de evins prin fapta deposedării, întrucât are un obiect pecuniar, se divide de plin drept între comoștenitori.

\section{A. Problematica și cadrul contextual al evingerii cumpărătorului în cazul bunurilor mancipi.}

Configurată la origini pentru transferarea bunurilor mobile (sclavii având statutul de bunuri mancipi), actul abstract al mancipatio a fost utilizat ulterior (cel târziu până în sec. al IV-lea p. Chr.) şi pentru transferarea 
proprietății imobilelor (a fondurilor agrare), fiind un mijloc de dobândire a proprietății conform dreptului civil roman (rezervat cetățenilor romani), astfel încât putea fi utilizat de către latini sau peregrini doar în mod excepțional, în măsura în care aceștia aveau ius commercii ${ }^{7}$. Fondate pe delictul comis de vânzătorul neproprietar, actio auctoritatis și actio de modo agri (în ipotezele în care mancipantul a declarat o suprafață mai mare a terenului decât cea înstrăinată în fapt) îl obligau pe vânzător la o rambursare in duplum a valorii prețului primit.

\section{B. Specificitatea efectelor vânzării consensuale romane.}

Generator de obligații bilaterale ${ }^{8}$, contractul consensual de vânzare în dreptul roman îl obliga pe vânzător doar la transmiterea posesiunii, iar nu a proprietății, din rațiuni ce țineau de celeritatea încheierii contractelor și de implicarea peregrinilor în operațiunile de comerț, peregrini care nu ar fi putut dobândi proprietatea civilă, rezervată cetățenilor romani. Marcată, totodată, de imperativele pragmatice ale comerțului cu sclavi, care, deși aveau statutul de bunuri mancipi, era nepragmatic să fie vânduți prin formalitățile mancipațiunii (care ar fi trebuit îndeplinite individual, pentru fiecare sclav în parte), vânzarea consensuală ridica doar problema transferului posesiei.

\footnotetext{
7 A se vedea M. D. Bob, Manual elementar de drept privat roman, ediția a II-a, Ed. Universul Juridic, București, 2019, p. 142-143.

${ }^{8}$ Idem, p. 248-249.
} 


\section{Regimul lui actio auctoritatis, anterior configurării răspunderii obiective pentru evicțiune}

Considerată a fi figura pivotantă pentru dezvoltarea garanției pentru evicțiune în dreptul roman, actio auctoritatis a fost reglementată în legea decemvirală, alături de actio de modo agri, în vechiul drept roman ${ }^{9}$. Vom analiza, în paragrafele care urmează, principalele linii de forță care configurează actio auctoritatis în dreptul roman vechi și clasic, pornind de la opiniile exprimate în literatura de specialitate cu privire la arhitectura acestui concept juridic.

\section{A. Actio auctoritatis, ca acțiune în reprimarea unui delict \\ 1. Actio auctoritatis: efect automat al mancipatiunii sau pact accesoriu?}

Natura juridică a lui actio auctoritatis rămâne controversată. Paul Frédéric Girard susținea că eventuala responsabilitate a vânzătorului decurgea din ideea de asistență procesuală ${ }^{10}$ pe care cel care transfera bunul

${ }^{9}$ Idem, p. 239.

10 P. F. Girard, Mélanges de droit romain, I. Etudes historiques sur la formation du système de la garantie d'éviction en droit roman, Recueil Sirey, Paris, 1923, p. 11: „L'auctor n'est ni celui qui transfère la proprieté, ni celui qui est tenue à garantie, c'est celui qui intervient dans une situation pour compléter, fortifier, c'est-â-dire, dans notre cas, celui qui assiste l'acquéreur dans le procés en revindication intenté contre lui et l'auctoritas ce n'est pas le mode d'acquerir, ni l'obligation â garantie, mais cette assistance même." Autorul citat sublinia că, dacă la origini auctoritas desemna actul material al asistenței procesuale efective acordate cumpărătorului în urma încheierii unei mancipațiuni, ulterior a sfârșit prin a desemna însăși obligația de garanție sau de intervenție procesuală în garanție a vânzătorului care participase la formalitățile mancipațiunii (p. 11): „Le terme auctoritas est arrivé à désigner au lieu de cet acte matériel et concret d'assistance dans un procés, l'obligation de fournir 
mancipi prin mancipațiune o datora față de accipiens, în eventualitatea în care accipiens s-ar fi confruntat ulterior cu chemarea sa în judecată de către un terț care introdusese o rei vindicatio. Semnificația primară a lui actio auctoritatis ar fi fost aceea de asistență procesuală a cumpărătorului de către vânzător în litigiul cu terțul care revendica bunul, ceea ce acaparează atenția fiind uzul binomului format din termenii actio și auctoritas, ultimul mecanism având funcția de legitimare a cumpărătorului ca proprietar al bunului în baza unui modus aquirendi valid, cu privire la dominium ex iure Quiritium. Dacă vânzătorul eșua în a oferi această asistență, auctoritatem defugere, rămânea obligat să restituie cumpărătorului dublul prețului încasat, cumpărătorul putând obține condamnarea sa la plata in duplum. Astfel configurată, actio auctoritatis genera pentru vânzător o obligație legală de intervenție procesuală și, ulterior, de indemnizare a cumpărătorului în cazul în care titlul terțului fusese recunoscut ca valid de către instanță, fundamentată pe riscul care plana pentru cumpărător de a fi contractat cu un non dominus. Alți autori, precum Carlo Longo, au susținut ${ }^{11}$ că prezența mancipantului alături de achizitor în procesul intentat de către terț este un efect intrinsec al participării acestora la formalitățile mancipației, fiind de esența procedeului de transmitere a proprietății civile per aes et libram ca cel care se pretindea proprietar ex iure Quiritium în fața celor cinci martori și a purtătorului de balanță să susțină ulterior postura de proprietar a

l'assistance, puis l'acte translatif de propriété à raison duquel cette obligation se produisait, enfin toute acquisition de propriété et le droit de propriété lui-même. On comprend cette extension progressive autant qu'on comprendrait peu l'évolution contraire. Mais dans l'acception primitive et technique, l'auctoritas est l'assistance fournie par le mancipant à son acquéreur."

${ }^{11}$ C. Longo, Corso di diritto romano, Ed. Giuffrè, Milano, 1937, p. 224, citată după S.A. Vernea, loc. cit. supra. 
cumpărătorului conform dreptului civil (aplicabil cetățenilor romani) şi, implicit, să aducă dovezi privind calitatea sa de proprietar, calitate în care ar fi participat la formalitățile mancipațiunii. Consecință directă și inevitabilă a postulării calității de proprietar ex iure Quiritium în procedeul mancipatio, de către cel care a urmărit să transmită cumpărătorului proprietatea asupra bunului manicipi, procedeul auctoritas ar fi derivat, astfel, din însăşi structura mancipațiunii, solemnitatea acesteia în fața martorilor presupunând în mod necesar ca, dacă ulterior titlul vânzătorului ar fi fost contestat, acesta (care a susținut în cadrul mancipațiunii, în mod solemn ${ }^{12}$, că deține proprietatea civilă asupra bunului) să intervină în procesul ${ }^{13}$ cu terțul pentru a încerca să clarifice situația juridică a bunului și, dacă evicțiunea avea totuşi loc, să îl indemnizeze pe cumpărător in duplum.

\section{Postulo anne auctor fias.}

În opinia lui Paul Frédéric Girard, intervenția mancipantului în procesul dintre cumpărător și terțul reclamant din acțiunea în revendicare nu

\footnotetext{
12 După cum s-a subliniat, din caracterul penal al lui actio auctoritatis decurgea consecința imposibilității introducerii sale contra succesorilor mancipantului decedat, răspunderea delictuală a acestuia având un pronunțat caracter personal. A se vedea P. F. Girard, op.cit., p. 43, care subliniază că, în opinia sa, delictul comis de către mancipant nu era acela de a fi mancipat un res aliena, vânzarea bunului altuia nefiind expres prohibită, ci delictul comis era acela de a nu-l fi apărat pe cumpărător, de a nu-i fi furnizat asistență procesuală pentru evitarea evicțiunii, după participarea la ritualul mancipațiunii: „On pourrait enfin remarquer que, si l'actio auctoritatis est une action pénale, elle ne pourra pas être intentée contre les héritiers du mancipant. (...) De plus, il serait peut-être permis de dire que, le délit consistant non pas à manciper une res aliena, mais à ne pas défendre un acquéreur par mancipation, ce délit est commis personnellement quand il ne fournit pas l'assistance. (...) Rien n'empêche donc de considérer notre action comme une action pénale ou plus exactement comme une action mixte appartenant à la victime d'un délit privé."

13 A se vedea, pentru dezvoltări, V. Hanga, „Răspunderea juridică în Legea celor XII Table”, Studii de drept românesc vol. 8 (41), nr. 3-4/1996, p. 261-273.
} 
avea ca efect, în procedura legis-acțiunilor ${ }^{14}$, scoaterea cumpărătorului pârât din proces. Această intervenție era urmarea unei notificări adresate de către cumpărător mancipantului, cu formularea „Quando in jure te conspicio postulo anne fias auctor" ${ }^{\prime \prime}$, însă de abia în procedura formulară vânzătorul se putea substitui cumpărătorului în litigiul cu terțul, ca un cvasi-reprezentant judiciar, pledând alieno nomine, în beneficiul cumpărătorului ${ }^{16}$. Obligația vânzătorului de asistență judiciară a cumpărătorului dura în timp până la împlinirea termenului necesar pentru a uzucapa conform legii civile (în epoca clasică, doi ani în cazul imobilelor şi un an, în cazul bunurilor mobile), posterior acestui moment al uzucapării fiind evident că pentru achizitor intervenția vânzătorului nu mai era necesară.

Pentru ca achizitorul să beneficieze de auctoritas posterior îndeplinirii formalităților mancipațiunii şi anterior survenirii uzucapiunii, era necesară îndeplinirea unei duble condiții, și anume ca acesta să fi achitat prețul către vânzător și să fi avut loc remiterea sau tradițiunea bunului mancipi în mâinile cumpărătorului ${ }^{17}$ (dublă condiție care, de altfel, era îndeplinită în cadrul ritualului mancipațiunii, de regulă, însă nu întotdeauna ${ }^{18}$ ).

14 Prin procedura sacramentum in rem.

15 A se vedea P. F. Girard, op.cit., p. 15-16.

16 În exprimarea lui P. F. Girard (cit. supra, p. 16): „(...) après l’introduction de la procédure formulaire et lorsqu'il fut permis de plaider alieno nomine, rien n'empêcha le vendeur de mettre l'acquéreur hors de cause en se constituant son représentant judiciaire."

17 Paulus, Sentent., 2,17,1: „Venditor si ejus rei quam vendiderit dominus non sit, pretio accepto, auctoritatis manet obnoxius, aliter enim non potest obligari"; de asemenea, Paulus, Sentent., 2,17,3: „Res empta, mancipatione et traditione perfecta si evincatur auctoritatis venditor duplo tenus obligatur”.

18 Având în vedere că, în cazul terenurilor, în cadrul mancipațiunii era adus un simbol al acestora (un bulgăre de pământ, de exemplu), punerea în posesie a cumpărătorului nu era 


\section{B. Nexum mancipiumque: un clivaj aparent?}

În literatura de specialitate ${ }^{19} \mathrm{~s}-\mathrm{a}$ opinat, cu privire la accepțiunea lui actio auctoritatis în vechiul drept roman, că răspunsurile la interogațiile generate de natura juridică a acesteia s-ar găsi în mecanismul și în principiile intrinseci aplicabile mancipațiunii în epoca veche și la începutul epocii clasice a dreptului roman. Textele Legii celor XII Table asociau procedeele nexum și mancipatio într-o expresie care, întrebuințând jocul conjuncției / disjuncției que, creau nu numai aparența unei perechi insolite, ci și premisele unui cuplu mai mult decât straniu: cel format dintr-un procedeu obligațional cu garantarea executării asupra persoanei debitorului (nexum), presupunând posibilitatea aplicării lui manus iniectio și, pe de altă parte, cel format dintrun mecanism de transferare a proprietății civile (mancipatio). Textul Cum nexum faciet mancipiumque, uti lingua nuncupassit, ita ius esto ${ }^{20}$ a suscitat multiple comentarii de-a lungul timpului, nu neapărat conciliante. Inițial, acest fragment a fost interpretat ca o expresie a codificării în vechiul drept roman $^{21}$ a două procedee distincte, unul generator de efecte obligaţionale, celălalt translativ de proprietate civilă, reunite în același text din rațiuni de economie a exprimării, enunțate fiind pe un ton spartan, aproape laconic. Dilemele interpretative s-au accentuat însă pornind de la conturarea unui

neapărat imediată, chiar dacă prețul trecea în mâinile vânzătorului (la origini, rolul libripensului în ritualul mancipațiunii fiind acela de a cântări metalul plătit ca preț).

19 A se vedea A. Magdelain, „L' acte juridique au cours de l' ancien droit romain”, în Jus imperium auctoritas. Études de droit romain, Publications de L’École Française de Rome, Roma, 1990, pp. 713-752, disponibil de asemenea la adresa https://www.persee.fr/doc/efr 000000001990 ant 13313984 , consultată în 08.09.2020.

${ }^{20}$ L.XII T.: 6,1.

${ }^{21}$ Evoluția acestor opinii este prezentată succint de A. Magdelain, op.cit., p. 742. 
răspuns la întrebarea: cine era subiectul procedeului uti lingua nuncupassit, creditorul sau debitorul din cadrul unui nexum, înstrăinătorul sau dobânditorul din cadrul mancipațiunii?

În interpretarea furnizată de romanistul Otto Lenel în 1902, nexum mancipiumque descrie două catene (efectul real și efectul obligațional) al unui procedeu unic, cel al mancipațiunii, în cadrul căreia nexum ar fi servit ca mecanism prin care vânzătorul se obliga să achite cumpărătorului dublul valorii lucrului vândut în eventualitatea evingerii acestuia de către un terțt22. La origini, în absența elementului verba al stipulației (in duplum) referitoare la garanția pentru evicțiune (de unde şi trimiterea expresă în textul citat la nexum), procedeul per aes et libram de transferare a proprietății civile nu ar fi putut genera efecte obligaționale în favoarea cumpăătorului, cu atât mai puțin, în caz de evicțiune, obligarea vânzătorului la plata dublului sumei primite. Explicația identificată de Otto Lenel la începutul secolului trecut viza procedeul nexum ca intrinsec mancipațiunii în vechiul drept roman (rămas, însă, la alegerea părţilor), pentru a putea genera obligarea in duplum a vânzătorului ca fațetă a garanției pentru evicțiune. În varianta arhaică a vânzării prin mancipatio, obligarea prin nexum preceda suita de elemente formaliste per aes et libram, părțile fixând (prin elementele obligaționale verba care precedau mancipațiunea) obiectul obligației, întinderea fondurilor agrare (bunuri mancipi) vândute, calitatea optimus maximus a fondului agrar, dacă era cazul. Părțile puteau opta pentru omiterea lui nexum, caz în care trecerea directă la formalitățile per aes et libram ar fi marcat, în vechiul

${ }^{22}$ Idem, p. 743-744, pentru preluarea detaliată a teoriei lui Otto Lenel. 
drept roman, absența ulterioară a unui mecanism specific garanției pentru evicțiune ${ }^{23}$.

Un posibil argument în favoarea tezei susținute de Otto Lenel pare a fi un fragment mutilat (regăsit incomplet) din Legea celor XII Table, care menționează procedeul nexum în contextul unui ius commercii (cel puțin parțial) acordat de Roma unor triburi vecine a căror origine se menține misterioasă pentru istorici: populațiile Forcti și Sanates ${ }^{24}$. Fragmentul Nex ... Forti Sanati ... ${ }^{25}$ reconstituit ca fiind Nexi mancipique Forti Sanatique idem ius esto (pornind de la un text al istoricului roman Festus) nu specifică dacă ius commercii era sau nu recunoscut acelor populații vecine în plenitudinea efectelor sale, însă are comun cu textul din Legea celor XII Table citat anterior (Cum nexum faciet mancipiumque, uti lingua nuncupassit, ita ius esto) faptul că plasează nexum în debutul ritualului dual, înaintea desfăşurării formalităților mancipațiunii ${ }^{26}$. Posterior interzicerii procedeului nexum prin Legea Poetelia Papiria ${ }^{27}$, mancipatio s-a desfășurat făă a fi precedată de stipulația pentru garanție contra evicțiunii, iar promisiunile verbale enunțate de înstrăinător au fost înlocuite cu leges mancipii, prin care înstrăinătorul, înainte de a da cuvântul achizitorului, descria bunul vândut şi condiția

23 Ibidem.

24 Idem, p. 744-745.

25 L. XII T.: 1,5 .

${ }^{26}$ A. Magdelain, op.cit., p. 744.

${ }^{27}$ Lex Poetelia-Papiria, care suprima efectul obligațional al lui nexum, interzicând creditorilor să execute persoana debitorului rău-platnic, a fost datată de Titus Livius cu anul $326 a$. Chr., considerându-se că ar fi fost adoptată în timpul celui de-al treilea mandat în calitate de consul al lui Gaius Poetelius Libo Visolus, însă Marcus Terentius Varro datează respectiva lege în anul 313 a. Chr., în timpul dictaturii fiului lui Poetelius (fost consul). 
juridică a acestuia ${ }^{28}$, similar preambulului oferit prin nexum în cadrul vechiului procedeu dual nexi mancipique. Adagiul uti lingua nuncupassit ${ }^{29}$ din Legea celor XII Table continua astfel să legitimeze, în epoca clasică a dreptului roman, clauzele anexate la mancipațiune sau stipulaţiile conexe vânzării în scopul conturării garanției pentru evicțiune datorate cumpărătorului ${ }^{30}$.

\section{Stipulațiile conexe vânzării și stipulatio duplae: remedii contra evicțiunii?}

Merită reamintit că de acţiunea examinată anterior, actio auctoritatis, nu putea beneficia decât cumpărătorul unui bun mancipi a cărui proprietate a fost dobândită de către acesta prin mancipatio, acest mecanism nefiind disponibil în cazul evicțiunii survenite în absența mancipațiunii ori în cazul

28 A. Magdelain, op.cit., p. 745.

29 În contextul abordării vânzării imobilelor, Cicero, în lucrarea De officiis, sublinia în mod expres că vânzătorul era obligat să restituie dublul valorii lucrului vândut (dupli poenam subiret): cum ex XII tab. satis esset ea praestari, quae essent lingua nuncupata, quae qui infitiatus esset, dupli poenam subiret, a iuris consultis etiam reticentiae poena est constituta (Cic. off. 3, 16, 65). Fragmentul citat are meritul de a asocia atât trimiterile exprese la prevederile Legii celor XII Table, din vechiul drept (cum ex XII tab. satis esset ea praestari), cât și ideea de validitate a clauzelor atașate vânzării în dreptul clasic (quae essent lingua nuncupata), pentru a regla consecințele patrimoniale ale evicțiunii. A se consulta J. Macqueron, Histoire des obligations. Le droit romain, Faculté de Droit et de Science Politique, Aix-en-Provence, 1971, p. 133-134, disponibil la adresa http://www.histoiredudroit.fr/Documents/Sources/macqueron_obligations.pdf, accesat în 19.09.2020; autorul citat subliniază că expresia qui infitiatus esset din textul lui Cicero se referă la vânzătorul care, în cadrul mancipațiunii, nu a comunicat (a ascuns adevărul despre) adevărata întindere a terenului vândut sau adevăratul statut juridic al bunului mancipi care făcea obiectul mancipațiunii.

$3^{0}$ Ibidem. 
bunurilor nec mancipi transferate prin traditio. În aceste cazuri, cumpărătorii preferau să încheie cu vânzătorul o stipulatio prin care vânzătorul să se oblige la despăgubiri în cazul eventualei evicțiuni. Prin intermediul acestora, vânzătorul se obliga să achite dublul sumei primite cu titlu de preț (stipulatio duplae), preluând astfel soluția pe care legea o prevedea în cazul bunurilor mancipi (chiar dacă, în aceste cazuri, ale unei stipulatio duplae voluntare, părțile fie nu participaseră la ritualul mancipațiunii, fie bunul nu fusese din start unul mancipi); de asemenea, în aceste cazuri, nefiind vorba despre bunuri mancipi vândute prin mancipatio, vânzătorul se putea obliga, dimpotrivă, printr-o stipulatio simplae, să achite cumpărătorului prețul încasat, în eventualitatea evingerii acestuia de către un terț. Erau, aşadar, necesare astfel de stipulații adiacente (unei vânzări convenite într-o altă formă decât cea a mancipațiunii), întrucât în absența unor garanții indirecte convenționale de acest fel, pe care să se fondeze ulterior o actio ex stipulatu ${ }^{31}$, cumpărătorul nu fi putut să se îndrepte contra vânzătorului în eventualitatea în care un terț ar fi invocat un titlu legitim asupra bunului.

$3^{1}$ A cărei natură era invariabil contractuală, iar nu delictuală, în pofida faptului că imita obiectul unei actio auctoritatis derivată dintr-o mancipatiune; în opoziție cu natura penală a lui actio auctoritatis, actio ex stipulatu nu sancționa un delict, ci deriva dintr-un angajament convențional. A se vedea P. F. Girard, op.cit., p. 41: „Que le délit soit limité au cas de mancipation, cela peut s'expliquer de mille façons, par exemple en admettant que les éléments du délit étaient fixés avant l'introduction de la vente dépourvue de formes. Quant à la satisdatio secundum mancipium et à la stipulatio duplae, nous verrons que ce sont deux engagements contractuels ayant à des degrés différents un objet imité de celui de l'actio auctoritatis. Assurément il ne s 'agit pas là de délit; mais c 'est qu'il y a un contrat et l'action, au lieu d'être l'actio auctoritatis, serra celle de ce contrat, l'actio ex stipulatu." 


\section{A. Mecanismele juridice ale satisdatio secundum mancipium sau repromissio secundum mancipium. garanții pentru vacua possessio?}

Primul dintre aceste mecanisme presupunea ca, prin intermediul unor formalități de tipul satisdatio (în accepțiunea de promisiune făcută în mod formal, verborum obligatio, a intervenției unui garant, care în epoca clasică era de regulă un fidejusor), vânzătorul să promită cumpărătorului că va interveni pentru a suporta din punct de vedere financiar prejudiciul rezultat dintr-o eventuală evicțiune, după modelul lui auctoritas specifică mancipațiunii ${ }^{32}$. Cât despre repromissio secundum mancipio ${ }^{33}$, aceasta reprezenta, de asemenea, o modalitate indirectă de garantare de către vânzător a cumpărătorului, prin care primul se obliga voluntar in duplum în pofida faptului că era vorba despre un bun nec mancipi sau se obliga in duplum chiar și pentru cazul în care mancipațiunea nu ar fi fost validă. Acest mecanism al repromissio era, de regulă, utilizat de către vânzătorul unui res mancipi care nu a putut îndeplini formalităţile mancipațiunii, nefiind obligat potrivit legii civile la auctoritas. În maniera descrisă, cumpărătorul beneficia de remedii similare celor derivate din actio auctoritatis, cu obligarea in duplum a vânzătorului în pofida neparticipării la formalităţile

\footnotetext{
$3^{2}$ Gaius, D.18,1,53: „...ut auctoritatis nomine venditor obligatur <res emptoris fiat> nihil interest utrum solutum sir pretium an eo, nomine fideiussor datus sit."

33 Secundum mancipio îmbracă, în această sintagmă, accepțiunea „imitând modelul mancipațiunii” sau „calchiind soluția din cadrul mancipațiunii” (obligarea vânzătorului la plata in duplum), cu diferența că mancipațiunea nu avusese loc, fie pentru că părțile aleseseră să evite formalitățile greoaie, fie pentru că transferaseră bunuri nec mancipi. A se vedea J. Belda Mercado, „La obligatión de garantía por evicción del comprador en el derecho romano clásico”, Anuario da Facultade de Dereito da Universidade da Coruña, nr. 8/2004, p. 119-140, disponibil de asemenea la adresa https://ruc.udc.es/dspace/handle/2183/2318, consultată în 08.09.2020.
} 
mancipațiunii ${ }^{34}$, însă bazându-se pe promisiunea solemnă făcută de vânzător. Garantându-i indirect liniștita posesiune a lucrului, vânzătorul promitea formal că îl va despăgubi cu dublul valorii lucrului în eventualitatea evingerii acestuia de către un terț.

\section{B. Cum funcționa stipulatio rem habere licere?}

În literatura de specialitate, s-a opinat, în privința sferei de aplicare a celor două categorii de stipulații, că stipulatio duplae se aplica în general bunurilor mancipi ${ }^{35}$ în ipotezele în care părțile nu îndepliniseră formalitățile unei mancipațiuni valide, în ideea de a suplini finalitatea pe care o îndeplinea actio auctoritatis în cadrul mancipațiunii, și anume obligarea vânzătorului la plata dublului prețului încasat de la cumpărătorul evins, în timp ce stipulatio rem habere licere era utilizată în cazul bunurilor nec mancipi ${ }^{36}$ sau, în general, în cazul bunurilor de valoare redusă, pentru a regla efectele patrimoniale ale eventualei evicțiuni care s-ar fi putut produce. Prin intermediul unei stipulatio habere licere, vânzătorul se garanta cumpărătorului posesiunea pașnică și utilă asupra bunului și că, în cazul în care va fi tulburat în stăpânirea liniștită a bunului, îi va achita id quod interest, în funcție de prejudiciul patrimonial suferit efectiv de către cumpărător. În

34 Ș. Mircioiu, Transferul dreptului de proprietate prin vânzare. Studiu de drept comparat, Ed. Universul Juridic, București, 2014, p. 47-55.

35 A se vedea J. Belda Mercado, op.cit., p. 134.

${ }^{36}$ Varro, De re rustica, 2,3,5: „De emptione aliter dico atquefit, quod capras sanas sanus nemo promittit, numquam enim sine febri sunt. Itaque stipulantur paucis exceptis verbis, ac Manilius scriptum reliquit sic: "Ulas capras hodie recte esse et bibere posse habereque recte licere, haec spondesne?»" În fragmentul citat, Varro exemplifică utilizarea stipulației rem habere licere în cazul animalelor destinate consumului (bunuri nec mancipi). Paragraful vizează însă garantarea cumpărătorului contra viciilor ascunse ale bunului vândut, iar nu problematica evicțiunii. 
opoziție cu efectele unei actio auctoritatis din cadrul mancipațiunii sau cu efectele unei stipulatio duplae, când cumpărătorul obținea un multiplu al sumei achitate cu titlu de preț, de regulă dublul acestei sume, întinderea obiectului unei stipulatio rem habere licere era incertă, raportându-se în fiecare caz în parte la prejudiciul efectiv suferit de către cumpărător, obiectul acțiunii fiind calibrat id quod interest, independent de valoarea prețului achitat iniţial și raportându-se la valoarea pierderii înregistrate de cumpărător la momentul evicțiunii ${ }^{37}$.

\section{Există un automatism al garantării pentru evicțiune în dreptul roman clasic?}

\section{A. Garanția pentru evicțiune în vânzarea consensuală.}

Având în vedere că, în dreptul clasic, vânzătorul nu transfera decât posesiunea liniștită și durabilă asupra lucrului, cumpărătorul nu putea recurge la actio auctoritatis, având în schimb la dispoziție o actio empti, o acțiune contractuală, al cărei specific rezidă în faptul că nu putea fi utilizată în afara situațiilor în care vânzătorul a comis un dol ${ }^{38}$, cunoscând el însuși faptul că vinde bunul altuia sau că bunul este grevat de sarcini nedeclarate. Așadar, administrarea probei intenției dolosive paraliza practic, de cele mai multe ori, încercarea cumpărătorului de a-l face responsabil pentru evicțiunea suferită. Pactele accesorii la care ne-am referit în paragrafele precedente erau

37 Idem, p. 133. A se vedea, de asemenea, G. Guilda, La tutela del compratore in caso di evizione fra garanzia e responsabilità. Soluzioni giurisprudenziali romane e problemi teorici attuali, Jovene Editore, Napoli, 2013, p. 23-27 și p. 59-63.

38 D.19,4,1 (Paul. lib. XXXII ad Edictum): „(...) Venditori sufficit ob evictionem se obligare, possessionem tradere, et purgari dolo malo; itaque si evicta res non sit, nihil debet." 
menite deseori să contracareze tocmai această stare faptică, a imposibilității dovedirii dolului comis de vânzător. Or, stipulațiile de garanție generau o obligație condițională, care devenea eficace în măsura în care evicțiunea se producea, dacă vânzătorul se obligase verbal față de cumpăător să îi achite valoarea bunului sau dublul acesteia ori chiar cvadruplul acestei valori. După cum s-a subliniat, garanțiile generate de aceste stipulații decurgeau din însuşi mecanismul stipulației, independent de acțiunile născute din contractul de vânzare şi aveau un caracter exclusiv voluntar, vânzătorul nefiind constrâns prin lege să consimtă la asemenea pacte suplimentare ${ }^{39}$. Doar la finele sec. I p. Chr., motivat pe considerații ce țineau de imperativele bunei-credințe contractuale, cumpărătorul îi putea solicita vânzătorului să încheie o astfel de stipulație, în măsura în care evicțiunea nu s-a produs încă.

Următorul pas l-a reprezentat admiterea, în prima jumătate a sec. al II-lea p. Chr., a ideii că, chiar și după producerea evicțiunii, cumpărătorul are la dispoziție o acțiune contractuală ${ }^{40}$, generată automat de contractul de vânzare, independent de culpa vânzătorului, pentru a solicita remedii în urma evingerii sale de către terț ${ }^{41}$. Schimbarea de optică, începând cu acest

39 H. Ankum, „Problems concerning laudatio auctoris and denuntiatio litis made by the buyer in classical Roman Law”, Fundamina, vol. 20, nr. 1/2014, p. 3-14, disponibil la adresa http://www.scielo.org.za/pdf/funda/v20n1/01.pdf, consultată în 22.09.2020.

40 M. D. Bob, Manual elementar de drept privat roman, cit. supra, p. 241.

${ }^{41}$ Dacă introducea o actio empti, cumpărătorul care a suferit o evicțiune putea recupera de la vânzător prețul achitat, după cum rezultă dintr-un pasaj clasic; D.21,2,60 (Iavolenus, lib. 11 ex Plautio): Si in venditore dictum non sit, quantum venditorem pro evictione praestare oporteat, nihil venditor praestabit praetor simplam evictionis nomine, et ex natura ex empto actionis hoc quod interest. Dimpotrivă, dacă părțile vânzării consensuale au convenit expres un acord ad duplum ca accesoriu al vânzării consensuale, vânzătorul putea fi obligat la restituirea dublului sumei încasate cu titlu de preț, în temeiul unei acțiuni contractuale; Paul. Sententiae, 2,17,3: Res empta, mancipatione et traditione perfecta, si evincatur, auctoritatis venditor duplo tenus obligatur; de asemenea, Paul. Sententiae 2,17,4: Distracta fundo, si quis 
moment, este radicală: părțile vânzării nu mai trebuie să convină expres, separat, cu privire la existența garanției contra evicțiunii, ci, dimpotrivă, acesta va fi un efect automat al vânzării, în schimb exonerarea de garanție a vânzătorului - iar nu obligația acestuia de a-l garanta pe cumpărător trebuind să facă obiectul unei clauze exprese. Se admite, aşadar, că, începând cu cea de-a doua jumătate a sec. al II-lea p. Chr., garanția pentru evicțiune va fi datorată automat cumpărătorului independent de dolul comis sau nu de către vânzător ${ }^{42}$, schimbarea de macaz fiind clară către o responsabilitate obiectivă, detaşată de elementul culpei.

Important de subliniat este că vânzătorul răspundea față de cumpărătorul evins ${ }^{43}$ ca o consecință a faptului de a nu-i fi asigurat acestuia posesiunea liniștită, inatacabilă și durabilă a lucrului vândut, chiar dacă vânzătorul a acționat cu bună-credință, de unde și caracterul obiectiv al răspunderii; însă, dacă era implicat un vânzător de rea-credință, care a vândut un bun cunoscând existența motivului de evicțiune și ascunzându-l cumpărătorului, acesta din urmă se putea îndrepta împotriva vânzătorului

de modo mentiatur, in duplum eius quod mentitus est, officio iudicis aestimatione facta convenitur.

42 E. Aguirre Cardona, E. Reigadas Lavandero, „El contrato de compraventa en derecho romano, derecho civil y proyectos de unificacion internacional”, Madrid, 2014, p. 6-44, disponibil la adresa https://repositorio.comillas.edu/jspui/bitstream/11531/644/1/TFG000555.pdf, consultată în 08.09.2020.

43 D.19,1,11,2 (Ulp. lib. XXXII ad Edictum): „Et in primis ipsam rem praestare venditorem oportet, id est tradere: quae res, si quidem dominus fuit venditor, facit et emptorem dominum, si non fuit, tantum evictionis nomine venditorem obligat, si modo pretium est numeratum, aut eo nomine satisfactum. Emptor autem nummos venditoris facere cogitur." 
fără a aștepta producerea evicțiunii, introducând o actio empti în încercarea de a dovedi dolul ${ }^{44}$ comis de vânzător ${ }^{45}$.

În cadrul vânzării romane consensuale, ceea ce justifică exercițiul dreptului cumpărătorului la remedii în cazul evicţiunii nu este absența transferului valabil al proprietății, întrucât acesta nu reprezenta un efect natural al vânzării consensuale, ci absența unei posesiuni liniştite şi durabile a cumpărătorului asupra bunului cumpărat. Astfel, până la momentul în care cumpărătorul nu era spoliat de posesiunea paşnică şi durabilă asupra bunului, acesta nu putea emite pretenții contra vânzătorului; însă, dacă acesta era privat de posesiunea asupra bunului ca urmare a revendicării bunului de către verus dominus, care invoca un titlu legitim, cumpărătorul se putea îndrepta contra vânzătorului în temeiul garanției pentru evicțiune ${ }^{46}$.

44 Desigur, în cazul dolului comis de vânzător, era ineficace eventualul pact asociat vânzării, prin care părțile ar fi convenit asupra exonerării vânzătorului de garanția pentru evicțiune. D.19,1,6,9 (Pomponius, lib. IX ad Sabinum): Si venditor sciens obligatum aut alienum vendidisset, et adiectum sit, neve eo nomine quid praestaret, aestimari oportet dolum malum eius, quem semper abesse oportet in iudicio empti, quod bonae fidei sit.

45 D.19,1,30 (lib. VIII Quaestionum): Si sciens alienam rem ignoranti mihi vendideris, etiam priusquam evincatur utiliter me ex empto acturum putavit in id, quanti mea intersit meam esse factam...; Qui sciens alienam, non suam ignoranti vendidit. Id est maxime, si manumissuro vel pignori daturo vendiderit.

${ }^{46}$ D.12,4,16 (Celsus, lib. 111 Digestorum): Dedi tibi pecuniam, ut mihi Stichum dares: utrum id contractus genus pro portione emptionis et venditionis est an nulla hic afio obligatio est quam ob rem dati re non secuta? In quod proclivior sum: et ideo, si mortuus est Stichus, repetere possum quod ideo tibi dedi, ut mihi Stichum dares. Finge, alienum esse Stichum, sed te tamen eum <tradidisse>; repetere a te pecuniam potero, quia hominem accipientis non feceris: et rursus, si tuus est Stichus, <et pro evictione eius > promittere non vis, non liberaberis, quo minus a te pecuniam repetere possim. 


\section{B. Denuntiandi necessitas: consecințele omiterii chemării în garanție a vânzătorului.}

Trecerea la viziunea obiectivă, desprinsă de elementul vinovăției vânzătorului, asupra garanției pentru evicțiune a fost acompaniată de creionarea unui set de condiții obligatorii pentru conduita procesuală a cumpărătorului confruntat cu pericolul evicțiunii: acesta trebuia să notifice vânzătorului existența litigiului, astfel încât acesta să intervină pentru a-l apăra în procesul intentat de terț. Absența chemării în garanție a vânzătorului (sau a avânzilor-cauza cu titlu universal ai acestuia) în termen util reverbera în mod dramatic asupra dreptului cumpărătorului la garanție contractuală, soluție perpetuată în legislațiile moderne (preluată în art. 1705 C. civ., în vigoare din 1 octombrie din 2011, respectiv în art. 1351 din vechiul Cod civil).

În literatura de specialitate $^{47} \mathrm{~s}$-a subliniat că este necesară o examinare distinctă și diferențiată a obligației cumpărătorului de a chema în garanție vânzătorul, înștiințându-l pe acesta despre existența unei rei vindicatio inițiată de un terț, în raport cu tripticul de ipoteze posibile: (i) situația în care obiectul transferului l-a făcut un res mancipi; (ii) situația în care părțile au convenit o stipulatio duplum; (iii) ipoteza încheierii unei emptio-venditio consensuale. În primul set de situații, pentru a-şi îndeplini obligația de auctoritas, înstrăinătorul (mancipio dans) trebuia să îl asiste pe mancipio accipiens în procedura de revendicare inițiată contra acestuia, în încercarea de a asigura un rezultat favorabil cumpărătorului.

\footnotetext{
47 H. Ankum, „Problems concerning laudatio auctoris and denuntiatio litis made by the buyer...", cit. supra, p. 3 .
} 


\section{Configurația garanției pentru evicțiune în dreptul român contemporan}

Condițiile garanției contra evicțiuniii ${ }^{48}$ sunt reglementate în textul art. 1695 C. civ., menționându-se faptul că vânzătorul „este de drept obligat” să îl garanteze pe cumpărător împotriva evicțiunii care l-ar împiedica total sau parțial în stăpânirea netulburată a bunului vândut. Potrivit paragrafului (2) al aceluiași articol, garanția este datorată împotriva evicţiunii ce rezultă din pretențiile unui terț numai dacă acestea sunt întemeiate pe un drept născut anterior datei vânzării și care nu a fost adus la cunoștința cumpărătorului până la momentul încheierii contractului de vânzare. De asemenea, în dreptul civil contemporan, garanția este datorată împotriva evicțiunii ce provine din fapte imputabile vânzătorului, chiar dacă acestea s-au ivit ulterior vânzării, cu mențiunea că, în acest din urmă caz, convențiile anticipatorii exoneratoare de garanție sunt ineficace juridic, în contextul faptei ilicite a vânzătorului. Nu în ultimul rând, cumpărătorul poate bloca încercarea vânzătorului de a evinge, paralizând pretențiile reclamantului vânzător prin invocarea excepției de garanție, având în vedere că, potrivit art. 1696 C. civ., „Acela care este obligat să garanteze contra evicțiunii nu poate să evingă.”

48 A se consulta D. Chirică, Tratat de drept civil. Contracte speciale. Volumul I. Vânzarea si schimbul, ed. a II-a, Ed. Hamangiu, București, 2017, p. 377-381; F. Deak, L. Mihai, R. Popescu, Tratat de drept civil. Contracte speciale. Vol. I. Vânzarea. Schimbul, ed. a 5-a, actualizată și completată, Ed. Universul Juridic, București, 2017, p. 214-218; R. Duminică, D. Iancu, „Quelques considérations sur l'éviction en droit comparé”, Revista Drept - Series Iurisprudentia, Universitatea „1 Decembrie 1918” Alba Iulia, nr. 12/2009, p. 122-124; M.-L. Belu Magdo, Contractul de vânzare in noul Cod civil, Ed. Hamangiu, București, 2014, p. 241257. 
Indivizibilitatea obligației de garanție este stipulată în cuprinsul art. 1697 C. civ., conform căruia „Obligația de garanție contra evicțiunii este indivizibilă între debitori.” Se impun unele precizări suplimentare în legătură cu caracterul indivizibil al garanției de evicțiune. Astfel, trebuie remarcat că obligația de garanție este indivizibilă, în sensul că acel cumpărător poate chema în garanție pe oricare din moștenitorii universali / cu titlu universal ai vânzătorului. În schimb, obligația vânzătorului de a repara prejudiciul suferit de evins prin fapta deposedării, întrucât are un obiect pecuniar, se divide de plin drept, dacă sunt mai mulți moștenitori.

În acest perimetru, se cuvine, de asemenea menționat că textul art. 1697 C. civ. introduce, cu titlu de noutate, principiul indivizibilității obligației de garanție pentru evicțiune între debitori, ca o manieră suplimentară de a proteja creditorul acestei obligații, respectiv cumpărătorul. Desigur, indivizibilitatea între debitori a obligației de garanție contra evicţiunii intervine în cazul transmiterii unui bun de către coproprietari ori in cazul decesului vânzătorului a cărui succesiune revine persoanelor cu vocație succesorală universală/cu titlu universal. Astfel, menționăm că indivizibilitatea între debitori postulată de art. 1697 C. civ. asigură cumpărătorului evins dreptul de angaja răspunderea oricăruia dintre debitori pentru a fi obligat integral, cu posibilitatea acestuia de regres pro parte contra celorlalți debitori ai obligației de despăgubire a cumpărătorului.

Modificarea sau înlăturarea convențională a garanţiei pentru evicţiune și problematica limitelor incidente în materia validităţii și a eficacităţii juridice a convențiilor exoneratoare sunt reglate în cuprinsul art. 1698 C. civ., care stipulează validitatea de principiu a clauzelor prin care părțile convin să extindă sau să restrângă obligația de garanție. De asemenea, exonerarea completă de garanție contra evicțiunii a vânzătorului este posibilă, cu excepția 
situațiilor în care acesta a comis dol, cunoscând motivul evicțiunii şi necomunicându-l cumpărătorului la momentul încheierii contractului.

Stipulația prin care obligația de garanţie a vânzătorului este restrânsă sau înlăturată nu îl exonerează pe acesta de obligația de a restitui prețul, după cum reține legiuitorul în cuprinsul art. 1698, alin. (2) C. civ., cu excepția cazului în care cumpărătorul și-a asumat expres riscul producerii evicțiunii, caz în care vânzarea devine un contract aleatoriu, antrenând pentru cumpărător riscul de a pierde suma achitată cu titlu de preț pentru bunul în privința proprietății căruia va fi evins de către terț.

Limitele clauzei exoneratoare de răspundere pentru evicțiune sunt trasate în art. 1699 C. civ., conform căruia culpa sau fapta ilicită a vânzătorului anihilează eficacitatea juridică a convenţiilor limitative de răspundere, astfel încât, în pofida faptului că s-a convenit că vânzătorul nu va datora nicio garanție, el răspunde totuși de evicțiunea cauzată ulterior vânzării prin faptul său personal ori de cea provenită din cauze pe care, cunoscându-le în momentul vânzării, le-a ascuns cumpărătorului. În acest perimetru, orice stipulație contrară este considerată nescrisă, astfel încât cumpărătorul nu poate renunța anticipat la dreptul său de a invoca garanția contra evicțiunii imputabile vânzătorului.

Admiterea acțiunii cumpărătorului în rezoluțiune judiciară a contractului, conform art. 1700 C. civ. este posibilă nu numai în cazul evicțiunii totale, ci și în cazul evicțiunii parțiale, însă doar dacă respectivul cumpărător a fost evins în privința unei părți din drepturile sale îndeajuns de semnificativă încât, dacă ar fi cunoscut evicțiunea, acesta nu ar mai fi încheiat contractul de vânzare.

Restituirea prețului la care este îndreptățit cumpărătorul evins implică rambursarea de către vânzător, conform prevederilor art. 1701 C. civ., a 
întregii sume încasate cu titlu de preț, chiar dacă, la data evicțiunii, valoarea bunului vândut a scăzut sau dacă bunul a suferit deteriorări semnificative ${ }^{49}$, datorate fie forței majore, fie neglijenței cumpăă̆torului (care, fiind de bunăcredință şi considerându-se pe sine proprietarul ${ }^{50}$ bunului, s-a comportat cu acesta după cum a apreciat oportun, în baza atributului de dispoziție conferit de dreptul de proprietate pe care acesta considera că îl deține în mod legitim).

În măsura în care cumpăătorul a obținut un beneficiu în urma deteriorărilor cauzate bunului, vânzătorul are dreptul să deducă din prețul restituit cumpărătorului, o sumă corespunzătoare acestui beneficiu. În ipoteza în care lucrul vândut are, la data evicțiunii, o valoare mai mare, din orice cauză, vânzătorul este dator să plătească cumpărătorului, pe lângă prețul vânzării, sporul de valoare acumulat până la data evicțiunii.

Pentru stabilirea cuantumului daunelor-interese cuvenite cumpărătorului evins, din textul art. 1702 C. civ. rezultă că acestea cuprind:

a) valoarea fructelor pe care cumpăătorul a fost obligat să le restituie celui care l-a evins;

b) cheltuielile de judecată efectuate de cumpărător în procesul cu cel ce l-a evins, precum şi în procesul de chemare în garanție a vânzătorului;

c) cheltuielile încheierii și executării contractului de către cumpărător;

d) pierderile suferite și câștigurile nerealizate de către cumpărător din cauza evicțiunii.

49 F. Deak, L. Mihai, R. Popescu, op.cit., p. 218-219; R. Duminică, D. Iancu, „Quelques considérations sur l'éviction en droit comparé”, cit. supra, p. 126; M.-L. Belu Magdo, op.cit., p. 256-259; D. Chirică, op.cit., p. 382.

$5^{0}$ I. Dobrinescu, „Metamorfozele proprietăţii și sistemul de drept neoroman”, Dreptul nr. 5/2020, p. 28-55; I. Dobrinescu, „Dreptul de proprietate: între individualism și colectivism”, Dreptul nr. 8/2020, p. 11-33. 
De asemenea, vânzătorul poate fi obligat să ramburseze el însuşi cumpărătorului (i) sau să se asigure că terțul evingător achită cumpărătorului (ii) toate cheltuielile pentru lucrările efectuate în legătură cu bunul vândut, fie că lucrările sunt autonome, fie că sunt adăugate, dar, în acest din urmă caz, numai dacă sunt implicate cheltuieli necesare sau utile, ultimele datorânduse cumpărătorului în limita sporului valoric obiectiv înregistrat de bun.

În ipotezele în care cumpărătorul poate proba dolul comis de vânzător, care a cunoscut cauza evicțiunii la data încheierii contractului, fără a o comunica achizitorului, vânzătorul poate fi obligat să ramburseze cumpărătorului inclusiv cheltuielile de lux, făcute pentru efectuarea și, după caz, pentru ridicarea lucrărilor care nu se încadrează nici în categoria celor necesare, nici în categoria lucrărilor utile.

Efectele evicțiunii parțiale asupra contractului de vânzare sunt trasate în art. 1703 C. civ., precizându-se că, în măsura în care evicțiunea parțială nu atrage rezoluțiunea contractului, vânzătorul trebuie să restituie cumpărătorului o parte din preț proporțională cu valoarea părții de care a fost evins și, dacă este cazul, să plătească acestuia daune-interese, pentru stabilirea întinderii cărora se vor aplica în mod corespunzător prevederile art. 1702 C. civ. ${ }^{51}$

În cazurile în care intervine înlăturarea evicțiunii de către cumpărător, consecințele vor fi cele trasate în textul art. 1704 C. civ.; astfel, în situația în care cumpărătorul a obținut sau a menținut în propriul său patrimoniu dreptul de proprietate asupra bunului cumpărat, plătind terțului evingător o sumă de bani sau dându-i un alt bun, vânzătorul va fi liberat de urmările garanţiei, în primul caz prin rambursarea către cumpărător a sumei plătite cu

${ }^{51} \mathrm{R}$. Popescu, „Efectele obligației de garanție în cazul evicțiunii consumate în reglementarea noului Cod civil,” Revista Universul Juridic nr. 6/2015, p. 36-47. 
dobânda legală calculată de la data plății (i), iar în al doilea caz, prin plata valorii bunului dat, precum și, în ambele cazuri, a tuturor cheltuielilor aferente (ii).

Chemarea în judecată a vânzătorului se menține în dreptul civil contemporan ca o premisă indispensabilă pentru conservarea dreptului la garanție de către cumpărător. Astfel, potrivit art. 1705 C. civ., cumpărătorul chemat în judecată de un terț care pretinde că are drepturi asupra lucrului vândut trebuie să îl cheme în cauză pe vânzător, iar în cazul în care a omis să procedeze în acest mod, iar acțiunea introdusă de terț a fost admisă, cumpărătorul va pierde dreptul de a invoca garanția pentru evicțiune, dacă vânzătorul dovedește că putea furniza suficiente probe şi apărări care să justifice respingea cererea terțului evingător. Dacă s-a produs o evicțiune extrajudiciară, cu acceptul cumpărătorului care, fără a exista o hotărâre judecătorească, a recunoscut dreptul terțului, acesta pierde dreptul de garanție, cu excepția cazului în care dovedește că atitudinea cumpărătorului a fost adecvată, întrucât nu existau motive suficiente pentru a împiedica evicţiunea.

Sfera subiectivă de incidență a dreptului la garanție contra evicțiunii (beneficiarii garanțiiei) a fost extinsă expressis verbis în cuprinsul art. $1706 \mathrm{C}$. civ., astfel încât, de lege lata, vânzătorul este obligat să garanteze contra evicțiunii față de orice dobânditor subsecvent al bunului, fără a deosebi între cazurile în care titlul subdobânditorului este unul gratuit sau unul oneros. Remarcăm, astfel, că, printre modificările majore aduse regimului garanțiilor vânzătorului în Codul civil în vigoare din 1 octombrie 2011, se numără și consacrarea expresă a existenței unei garanții ascendente pentru evicțiune. Prin angrenarea acestei garanții, dacă acelaşi bun a fost revândut, oricare dintre subdobânditorii bunului pot acționa în judecată pe vânzătorul anterior 
din şirul de vânzări consecutive, întrucât, conform art. 1706 C. civ., „Vânzătorul este obligat să garanteze contra evicțiunii față de orice dobânditor subsecvent al bunului, fără a deosebi după cum dobândirea este cu titlu oneros ori cu titlu gratuit".

Această posibilitate nu era interzisă în textele vechiului Cod civil de la 1865, însă nefiind consacrată expres, atât părțile, cât și judecătorii erau reticenți în ceea ce privește utilitatea sa ${ }^{52}$. Apreciem că situația primului vânzător nu este îngreunată prin consacrarea legislativă a acestei acțiuni, întrucât vânzătorul inițial este prin ipoteză dator să-l garanteze pentru evicțiune pe cumpărătorul intermediar. În schimb, situația cumpărătorului final se ameliorează considerabil, în cazurile în care autorul său direct (ultimul vânzător) este insolvabil, restituirea prețului ori reducerea acestuia putând fi obținută de la vânzătorul inițial, consecutiv evicţiunii ${ }^{53}$.

52 În contextul în care Codul civil român din 1864 nu reglementa expres existența unei acțiuni ascendente în garanție pentru evicțiune în cazul unor vânzări succesive, un segment al literaturii de specialitate considera că, în pofida faptului că subdobânditorul nu dobândește un drept nou, ci un drept retransmis, acesta nu avea posibilitatea să introducă o acțiune directă față de primul vânzător, datorită inexistenței unui raport juridic contractual între aceștia. Reverberațiile principiului res inter alios acta ar fi impus, în această optică, ideea că un cumpărător subsecvent, fiind terț în raport cu primul vânzător, nu ar putea acționa în garanție pentru evicțiune decât împotriva autorului său direct, vânzătorul cu care a contractat. Se admitea însă că acțiunea putea fi introdusă pe cale oblică, caz în care soluția era doar parțial avantajoasă, întrucât subdobânditorul venea în concurs cu creditorii vânzătorului intermediar și suporta concurența acestora la redistribuirea sumei rezultate din angrenarea garanției pentru evicțiune; a se vedea, în acest sens, pentru considerații asupra precedentei reglementări, I. Popa, Contractul de vânzare-cumpărare. Studiu comparativ de doctrină şi jurisprudență, ed. a 2-a, Universul Juridic, București, 2008, p. 358-361. Alți autori au opinat că garanția pentru evicțiune se transmitea și cumpărătorilor sau donatarilor aceluiaşi bun, chiar și sub imperiul vechiului Cod civil (a se vedea C. Toader, Evicțiunea în contractele civile, Ed. All Beck, București, 1997, p. 24 și urm.

53 D.A. Gidro, „Acțiunea directă a subdobânditorului împotriva primului vânzător în contextul noului Cod civil”, Revista Română de Drept Privat nr. 6/2015, p. 87. 
O altă remarcă ține de faptul că avantajele garanției ascendente pentru evicțiune se grupează în jurul ideii că aceasta evită multiplicarea acțiunilor în garanție cu privire la același caz de evicțiune și stopează șirul inutil și costisitor de litigii antrenate de evicțiune. Întrucât cauza evicțiunii a fost prezentă la momentul primei vânzări, dacă ultimul vânzător ar fi condamnat la cererea celui din urmă achizitor și nu ar exista această garanție ascendentă, este de presupus că pârâtul ar chema ulterior în garanție la rândul său, pe propriul său autor - vânzătorul intermediar - care va putea acționa în garanție pe cel de la care el însuși a cumpărat și tot astfel până la primul vânzător.

Garanția ascendentă pentru evicțiune nu trebuie confundată cu cazurile de garanție directă indivizibilă la care se referă art. 1697 C. civ., conform căruia „Obligația de garanție contra evicțiunii este indivizibilă între debitori”. Textul art. 1697 C. civ. se referă, dimpotrivă, la ipotezele practice caracterizate prin transmiterea proprietății unui bun de către coproprietari (i) ori la cazul decesului vânzătorului între momentul încheierii contractului de vânzare ș i momentul survenirii evicţiunii pentru cumpărător, vânzătorul defunct fiind moștenit de succesori cu vocație universală / cu titlu universal (ii). Indivizibilitatea între debitori asigură cumpărătorului dreptul de a antrena garanția pentru evicțiune contra oricăreia dintre persoanele care figurează la poziția „vânzător” în contractul de vânzare (o garanție directă, iar nu ascendentă), pentru a fi obligat integral la plata de despăgubiri, cu posibilitatea pârâtului de a se îndrepta în regres contra celorlalți debitori. Or, garanția ascendentă pentru evicțiune instaurată ca posibilitate pentru cumpărătorul subsecvent prin textul art. 1706 C. civ. nu generează o solidaritate pasivă între vânzătorii succesivi ai bunului, această posibilitate nefiind prevăzută de legiuitor. 
Ipotezele în care bunul a făcut obiectul mai multor vânzări succesive sunt relativ frecvente, în practică, la dispoziția ultimului cumpărător (evins) existând calea acțiunii în garanție, pe temei contractual, împotriva vânzătorului său direct. Două neajunsuri pot surveni însă, pentru subdobânditorul aflat pe poziția finală în lanțul de transmisiuni succesive: repararea efectivă a prejudiciului și recuperarea prețului să fie blocată de insolvabilitatea vânzătorului intermediar sau cumpărătorul intermediar să probeze că motivul evicțiunii este anterior contractului încheiat cu achizitorul final, cauza evicţiunii fiind prezentă la momentul primei vânzări. Considerăm că acest binom poate fi evitat prin angrenarea garanției ascendente pentru evicţiune. Acțiunea subdobânditorului la care se referă art. 1706 C. civ. este cea a autorului său, vânzătorul intermediar contra primului vânzător, astfel încât, ca regulă generală, va fi supusă regimului contractului originar, la care cel dintâi vânzător - pârât în această acțiune - și-a dat consimțământul ${ }^{54}$. Transmiterea garanției la subdobânditor poate fi fundamentată pe ideea unui transfer al acțiunii în garanție ca accesoriu al proprietății asupra lucrului. Raționamentul se aplică independent de caracterul gratuit ${ }^{55}$ sau oneros al transmisiunii la subdobânditor; indispensabil este doar ca autorul său să fi deținut o acțiune în garanție care să treacă, împreună cu bunul, la avânziicauză cu titlu particular la care se referă art. 1706 C. civ.

54 I. Sferdian, „Efectele bunei-credințe asupra garanției ascendente pentru evicţiune”, postat în 20.04.2017, disponibil la adresa https://www.juridice.ro/506265/efectele-bunei-credinteasupra-garantiei-ascendente-pentru-evictiune.html, consultată în 30.10.2020.

55 De exemplu, A i-a vândut un teren intravilan lui B prin act autentic, iar B i-a achitat suma de 85.00o euro. Ulterior B donează prin act autentic terenul către $\mathrm{C}$, iar C este evins de către $\mathrm{D}$, care într-o acțiune în revendicare dovedește că este adevăratul proprietar, întrucât vânzătorul A nu era adevăratul moștenitor al bunului. 
În ceea ce privește situația donatarului evins, acesta nu beneficiază de garanție contra evicțiunii în baza contractului de donație contra donatorului, însă respectând textul art. 1706 noul C. civ. va putea face uz de garanția pentru evicțiune datorată donatorului de către vânzătorul de la care acesta a achiziționat bunul. Menționăm că garanția pentru evicțiune nu este generată direct de contractul de donație, cu excepțiile cunoscute ale promiterii exprese de garanție, dolului comis de donator (care va transpune însă litigiul în plan delictual), al răspunderii în limita sarcinilor ce însoțesc donația. $\mathrm{Cu}$ toate acestea, prin antrenarea garanției ascendente pentru evicţiune subdobânditorul donatar ar urma să primească de la vânzătorul bunului (autor al donatorului) suma plătită cu titlu de preț în contractul primar, suma de bani înlocuind astfel în patrimoniul donatarului proprietatea bunului în privința căreia a fost evins.

Caracterul patrimonial, iar nu personal al garanției pentru evicțiune permite transmisiunea acțiunii în garanție la subdobânditorii bunului (universali, cu titlu universal sau particular), independent de caracterul oneros sau gratuit al titlului subdobânditorului. Necunoaşterea cauzei de evicțiune se apreciază în persoana cumpărătorului intermediar, astfel încât cunoașterea și asumarea motivului de evicțiune la momentul cumpărării bunului de către primul cumpărător face ca acesta să nu beneficieze de o acțiune în garanție care să se transmită la subdobânditor o dată cu revânzarea lucrului.

\section{Concluzii}

Creionată la început ca un răspuns judiciar la delictul comis de vânzătorul neproprietar, de a nu-l fi protejat pe cumpăător în litigiul contra 
terțului evingător, actio auctoritatis îl obliga pe vânzător la o rambursare in duplum a valorii prețului primit. Remediul descris era însă prezent numai pentru cumpărătorul unui bun mancipi a cărui proprietate a fost dobândită de către acesta prin mancipatio, fiind inexistent în cazul evicțiunii survenite în absența mancipațiunii ori în cazul bunurilor nec mancipi transferate prin traditio. Următoarele concluzii pot fi desprinse pe marginea considerațiilor de mai sus:

(a) în absența unei mancipațiuni valide ori în cazul bunurilor nec mancipi transferate prin traditio, părțile obișnuiau să recurgă la garanții indirecte convenționale, pe care să se fondeze ulterior o actio ex stipulatu, prin care cumpărătorul ar fi putut să se îndrepte contra vânzătorului în eventualitatea în care un terț ar fi invocat un titlu legitim asupra bunului;

(b) prin intermediul unor formalități de tipul satisdatio secundum mancipio (în accepțiunea de promisiune făcută în mod formal, verborum obligatio, a intervenției unui garant), vânzătorul putea să promită cumpărătorului că va interveni pentru a suporta din punct de vedere financiar prejudiciul rezultat dintr-o eventuală evicțiune (sau chiar de a rambursa cumpărătorului dublul prețului încasat), după modelul lui auctoritas specifică procedeului mancipatio;

(c) de asemenea, calchiind efectele pe care le-ar fi produs auctoritas, părțile puteau utiliza o repromissio secundum mancipio, ca modalitate indirectă de garantare de către vânzător a cumpărătorului, prin care primul se obliga voluntar in duplum în pofida faptului că era vorba despre un bun nec mancipi sau se obliga in duplum chiar și pentru cazul în care mancipațiunea nu a fost valabil îndeplinită pentru bunurile mancipi; vânzătorul promitea formal că îl va despăgubi cu dublul valorii lucrului în eventualitatea evingerii acestuia de către un terț; 
(d) începând cu prima jumătate a sec. al II-lea p. Chr., chiar și după producerea evicțiunii, cumpărătorul va avea la dispoziție o acțiune contractuală, generată automat de contractul de vânzare, independent de culpa vânzătorului, pentru a solicita remedii în urma evingerii sale de către terț.

(e) în urma acestei schimbări de optică, părțile vânzării nu vor mai conveni expres cu privire la existența garanției contra evicțiunii, care era deja văzută ca un efect automat al vânzării; în schimb, exonerarea de garanție a vânzătorului trebuia să facă obiectul unei clauze exprese, nefiind validă în cazul dolului comis de către vânzător;

(f) în cazul contratului consensual de vânzare, în ipoteza în care vânzătorul era de rea-credință, întrucât a vândut un bun cunoscând existența motivului de evicțiune și ocultându-l în raporturile cu cumpărătorul, acesta din urmă se putea îndrepta contra vânzătorului fără a aştepta producerea evicțiunii, introducând o actio empti în încercarea de a proba dolul comis de vânzător;

(g) caracteristic vânzării romane consensuale era faptul că ceea ce justifica exercițiul dreptului cumpărătorului la remedii în cazul evicțiunii nu era absența transferului valabil al proprietății, întrucât acesta nu reprezenta un efect natural al vânzării consensuale, ci faptul de a nu fi asigurat cumpărătorului posesiunea liniştită şi durabilă asupra bunului cumpărat;

(h) în ceea ce privește reglementarea garanției pentru evicțiune în dreptul român contemporan, admiterea acțiunii cumpărătorului în rezoluțiune judiciară a contractului, conform art. $1700 \mathrm{C}$. civ. este posibilă nu numai în cazul evicțiunii totale, ci și în cazul evicțiunii parțiale, însă doar dacă respectivul cumpărător a fost evins în privința unei părți din drepturile sale 
îndeajuns de semnificativă încât, dacă ar fi cunoscut evicțiunea, acesta nu ar mai fi încheiat contractul de vânzare;

(g) restituirea prețului la care este îndreptăţit cumpărătorul evins implică rambursarea de către vânzător, conform prevederilor art. 1701 C. civ., a întregii sume încasate cu titlu de preț, chiar dacă, la data evicțiunii, valoarea bunului vândut a scăzut sau dacă bunul a suferit deteriorări semnificative , datorate fie forței majore, fie neglijenței cumpărătorului, care, fiind de bunăcredință și considerându-se pe sine proprietarul bunului, s-a comportat cu acesta după cum a apreciat oportun, în baza atributului de dispoziție conferit de dreptul de proprietate pe care acesta considera că îl deține în mod legitim;

(i) modificarea sau înlăturarea convențională a garanției pentru evicțiune în dreptul contemporan este posibilă cu respectarea limitelor trasate în art. 1698 C. civ., care stipulează validitatea de principiu a clauzelor prin care părțile convin să extindă sau să restrângă obligația de garanție; de asemenea, exonerarea completă de garanţie contra evicţiunii a vânzătorului este posibilă, cu excepția situațiilor în care acesta a comis dol, cunoscând motivul evicțiunii și necomunicându-l cumpărătorului la momentul încheierii contractului. 


\section{Bibliografie}

E. Aguirre Cardona, E. Reigadas Lavandero, El contrato de compraventa en derecho romano, derecho civil y proyectos de unificacion internacional, Madrid, 2014, p. 6-44;

H. Ankum, „Problems concerning laudatio auctoris and denuntiatio litis made by the buyer in classical Roman Law", Fundamina, vol. 20, nr. 1/2014, p. 3-14;

J. Belda Mercado, „La obligatión de garantía por evicción del comprador en el derecho romano clásico", Anuario da Facultade de Dereito da Universidade da Coruña, nr. 8/2004, p. 119-140;

M.-L. Belu Magdo, Contractul de vânzare in noul Cod civil, Ed. Hamangiu, București, 2014;

M. D. Bob, Obligația contractuală în dreptul roman cu trimiteri comparative la Codul civil, Ed. Universul Juridic, București, 2015;

M. D. Bob, Manual elementar de drept privat roman, editia a II-a, Ed. Universul Juridic, București, 2019;

D. Chirică, Tratat de drept civil. Contracte speciale. Volumul I. Vânzarea si schimbul, ed. a II-a, Ed. Hamangiu, București, 2017;

F. Deak, L. Mihai, R. Popescu, Tratat de drept civil. Contracte speciale. Vol. I. Vânzarea. Schimbul, ed. a 5-a, actualizată și completată, Ed. Universul Juridic, București, 2017;

I. Dobrinescu, „Metamorfozele proprietății și sistemul de drept neoroman”, Dreptul nr. $5 / 2020$, p. $28-55$;

I. Dobrinescu, „Dreptul de proprietate: între individualism și colectivism”, Dreptul nr. 8/2020, p. 11-33; 
R. Duminică, D. Iancu, „Quelques considérations sur l'éviction en droit comparé”, Revista Drept - Series Iurisprudentia, Universitatea „1 Decembrie 1918” Alba Iulia, nr. 12/2009, p. 122-128;

D. A. Gidro, „Acțiunea directă a subdobânditorului împotriva primului vânzător în contextul noului Cod civil”, Revista Română de Drept Privat nr. 6/2015, p. 87-98;

P. F. Girard, Mélanges de droit romain, I. Etudes historiques sur la formation du système de la garantie d'éviction en droit roman, Recueil Sirey, Paris, 1923;

G. Guilda, La tutela del compratore in caso di evizione fra garanzia e responsabilità. Soluzioni giurisprudenziali romane e problemi teorici attuali, Jovene Editore, Napoli, 2013;

V. Hanga, Mari legiuitori ai lumii: Hammurabi, Iustinian, Napoleon, Ed. Lumina Lex, București, 1994;

V. Hanga, „Răspunderea juridică în Legea celor XII Table”, Studii de drept românesc vol. 8 (41), nr. 3-4/1996, p. 261-273;

C. Hochart, La garantie d'éviction dans la vente, L.G.D.J, Paris, 1993;

J. Macqueron, Histoire des obligations. Le droit romain, Faculté de Droit et de Science Politique, Aix-en-Provence, 1971;

A. Magdelain, „L'acte juridique au cours de l'ancien droit romain”, în Jus imperium auctoritas. Études de droit romain, Publications de L'École Française de Rome, Roma, 1990, pp. 713-752;

Ș. Mircioiu, Transferul dreptului de proprietate prin vânzare. Studiu de drept comparat, Ed. Universul Juridic, București, 2014;

I. Popa, Contractul de vânzare-cumpărare. Studiu comparativ de doctrină și jurisprudență, ed. a 2-a, Universul Juridic, București, 2008;

I. Popa, Contracte civile. De la teorie la practică, ediția a 2-a, Ed. Universul Juridic, București, 2020; 
R. Popescu, „Efectele obligației de garanție în cazul evicțiunii consumate în reglementarea noului Cod civil,” Revista Universul Juridic nr. 6/2015, p. 3647 ;

I. Sferdian, „Efectele bunei-credințe asupra garanției ascendente pentru evicțiune”, postat în 20.04.2017, disponibil la adresa https://www.juridice.ro/506265/efectele-bunei-credinte-asupra-garantieiascendente-pentru-evictiune.html, consultată în 30.10.2020;

V. Stoica, E. Garjau, „Practical notions regarding the contractual provision of the warranty against the eviction of selling contracts", AGORA International Journal of Juridical Sciences, nr. 2/2018, p. 85-91;

C. Toader, Evicțiunea în contractele civile, Ed. All Beck, București, 1997;

S. A. Vernea, „Warranty Against Eviction in Roman Law: A Conventional or Legal Obligation?", în Social Economic Debates, vol. 3, nr. 1/2014, p. 66-71;

M. Vols, A. Belloir, S.M. Hoffmann, A. Zuidema, „Common Trends in Eviction Research: A Systematic Literature Review", University of Groningen Faculty of Law Research Paper Series, nr.29, 2019, p. 23-78. 